\title{
Studies on diversity indices and insect pest damage of walnuts in Kashmir, India
}

\author{
Shaziya GULL ${ }^{1}$, Tariq AHMAD ${ }^{* 1}$, Ajaz RASOOL ${ }^{1}$ \\ Received November 20, 2018; accepted February 26, 2019. \\ Delo je prispelo 20. novembra 2018, sprejeto 26. februarja 2019.
}

\begin{abstract}
Walnut industry, one of the economically important industries of Kashmir is under multitude of stresses like changing weather patterns, international competition, insect pest damage and diseases. Pest damage by various insect species is by for the main cause of walnut damage, thus limiting its production. In this backdrop, the aim of the present study was to check the insect pest diversity and its nature and extent of damage to walnuts. Sampling was done fortnightly in three districts of Central Kashmir viz., Srinagar, Budgam, Ganderbal from June 2014 to November 2015. Quantitative estimation of individual species was made by using various diversity indices and each site varied in species diversity, richness and evenness. A total of nine sites were selected from three different districts and the insects collected belonged to 3 orders, 7 families and 10 species. Order Hemiptera was highly damaging in comparison to Coleoptera and Lepidoptera while in Hemiptera, maximum damage was done by Chromaphis juglandicola (Kaltenbach, 1843) and the least by Apodiphus pilipes (Horvath,1889). The study provides a baseline data for assessing the biodiversity pattern and damaging potential of walnut pests so as to develop holistic integrated pest management programme.
\end{abstract}

Key words: Juglans regia L.; diversity indices; incidence; infestation; species richness; walnut pests

\section{IZVLEČEK}

\section{RAZISKAVE DIVERZITETNIH INDEKSOV IN ŠKOD ZARADI ŠKODLJIVIH ŽUŽELK NA NAVADNEM OREHU V KAŠMIRJU, INDIJA}

Pridelovanje orehov, ki je ena izmed ekonomsko najvažnejših kmetijskih dejavnosti v Kašmirju, je soočeno s številnimi izzivi kot so podnebne spremembe, mednarodna konkurenca in škode zaradi škodljivcev in bolezni. Škode zaradi različnih žuželk predstavljajo glavni vzrok zmanjšane pridelave. Namen te raziskave je bil preveriti pestrost škodljivcev in obseg škod, ki jih ti povzročajo pri gojenju oreha. Vzorčenje je bilo izvedeno $\mathrm{v}$ štirinajstdnevnih presledkih $\mathrm{v}$ treh območjih osrednjega Kašmirja, Srinagar, Budgam, Ganderbal, v obdobju od junija 2014 do novembra 2015. Količinsko določanje posameznih vrst škodljivcev je bilo določeno $\mathrm{z}$ različnimi diverzitetnimi indeksi. Vsako izmed območij se je razlikovalo v pestrosti, bogatosti in izenačenosti vrst. Iz vseh treh raziskanih območij je bilo izbranih osem lokacij, na katerih so ujete žuželke pripadale 3 redovom, 7 družinam in 10 vrstam. Škodljivci iz redu Hemiptera so povzročili največ škode, $\mathrm{v}$ primerjavi $\mathrm{s}$ tistimi iz redov Coleoptera in Lepidoptera, med vrstami iz redu Hemiptera, je največ škode povzročila vrsta Chromaphagis juglandicola (Kaltenbach, 1843) in najmanj Apodiphus pilipes (Horvath,1889). Raziskava daje osnovne podatke za ocenjevanje vzorcev biodiverzitete in potencialnih škod zaradi škodljivcev na navadnem orehu pri razvoju celostnega integriranega programa upravljanja s škodljivci.

Ključne besede: Juglans regia L., diverzitetni indeksi; pojav; okužba; vrstna pestrost; škodljivci navadnega oreha

\footnotetext{
1 Entomology Research Laboratory, Postgraduate Department of Zoology, University of Kashmir, Srinagar, Jammu \& Kashmir, India-190006; *corresponding author: drtariqento@kashmiruniversity.ac.i
} 


\section{INTRODUCTION}

Regarded as heaven on earth, the state of Jammu \& Kashmir is called the biomass state of India due to its immense biodiversity, rich gene pool and priceless resources. Common Walnut (Juglans regia L.), one of the prime industries among various other commercial sectors of the valley, is cultivated in districts like Poonch, Pulwama, Anantnag, Ganderbal, Kulgam, Budgam, Kupwara, Baramulla and Srinagar. Among these districts, Shopian was on the forefront in walnut production in the past. The trend has changed and nowadays Kupwara is leading in walnut production (Directorate of Horticulture, 2015). So far as global scenario of walnut production is concerned, China is at the top followed by USA, Iran, Turkey, Ukraine, Romania, France and India while in recent years other countries like Argentina and Chile have also increased production of walnuts manifolds (Martinez et al., 2004). Irrespective of its significance, walnut production is threatened by insect pests and diseases, damaging fruit kernel, leaves, branches and trunk of walnut trees as reported by Mir \& Wani (2005). Most of the insect pests reported on walnuts are leaf defoliators, feeding on the leaves, twigs and branches leading to nut drop (Abbas et al., 2015). Among different insect orders, Coleoptera forms an important group of pests feeding on foliage and affecting photosynthetic surface of leaves (Mohandas et al., 2004). Larvae of certain pests form long tunnels inside stem and root and feed on the internal tissue advancing upwards (Khan et al., 2013). The attacked tree eventually accedes to injury by getting hollow inside and finally causes death of a plant. Certain dipteran flies also feed inside the walnut husk, causing blackening of shells and thereby reducing its market value (Boyce, 1934). Walnut aphids directly influence walnut production by accumulating honeydew on the husk, in turn attracting sooty mould. It has phytotoxic effect leading to general blackening of leaf surface (Boyce, 1934; Bhagat, 1986; Ahmed \& Ahmed, 2013). As the diverse insect pests attack and reduce walnut production worldwide, therefore, there is an urgent need to study the pest diversity and damage to walnuts especially in Kashmir where walnuts are organically produced. Conversely, the data will in turn enable us to develop planned integrated pest management strategy for walnut pests.

\section{MATERIAL AND METHODS}

\subsection{Study area and surveys}

The field surveys were conducted in three districts of Central Kashmir viz., Srinagar (34 04' $54.36^{\prime \prime} \mathrm{N}, 74^{\circ} 48^{\prime}$ $\left.33.00^{\prime \prime} \mathrm{E}\right)$, Budgam ( $\left.34^{\circ} 01^{\prime} 2.05^{\prime \prime} \mathrm{N}, 74^{\circ} 43^{\prime} 6.71^{\prime \prime} \mathrm{E}\right)$ and Ganderbal ( $\left.34^{\circ} 13^{\prime} 39.11^{\prime \prime} \mathrm{N}, 74^{\circ} 466^{\prime} 19.78^{\prime \prime} \mathrm{E}\right)$. During surveys, the distribution of insect pests and predators along with their mode of damage was recorded. From each district, three sites were selected based on the accessibility and availability of walnut trees viz., S1, S2 \& S3 in district Srinagar, G1, G2 \& G3 in district Ganderbal and B1, B2 \& B3 in district Budgam.

\subsection{Sampling methods}

For aphid study, sampling was done fortnightly by selecting five trees randomly in each walnut orchard ecosystem. Twenty sub terminal leaves were randomly selected from lower and middle canopy in each direction (East, West, North, South) making a total of 100 leaflets/orchard (Tomanović, 1996; UCIPM, 2011) Similarly, pests were calculated by direct count method In order to check the abundance at each site. For the study of beetle infestation and population counting, collection was done by 'one man - one hour method' by sweep nets in the early morning hours (Khairmode \& Sathe, 2014). Likewise, random selection was also done for collecting larvae of butterflies and moths while examining five trees from each orchard and selecting 100 leaves per tree with a total of 500 leaves per orchard. The nut borers were collected by random selection of two branches from opposite directions. The infested and dropped fruits were also analyzed for pest infestation (Mir \& Wani, 2005; Khan et al., 2013). Active fliers like bugs were collected by net sweeping method. Each sweep was repeated after a gap of 10 minutes with an overall 10 sweeps at one time (Kumar \& Naidu, 2010). Each walnut orchard which was evaluated for pest diversity was free from any kind of pesticide application. The collected insect pest specimens comprised of adults and nymphs (both mature and immature) and were preserved in $75 \%$ alcohol for further identification in Entomological Research Laboratory, Department of Zoology, University of Kashmir.

\subsection{Identification}

Identification and labelling was done as per the available literature and running taxonomic keys while the specimens which couldn't be identified or doubted were sent to Zoological Survey of India (ZSI), Kolkata, India for further confirmation. 


\subsection{Estimation of diversity indices}

Quantitative estimation of individual species was made using the data derived from field surveys. Margalef's richness index, Shannon-Wiener diversity index, Simpson's diversity index and Pielou's index were applied for studying the diversity and abundance of walnut insect pests. The formulae for various statistical/ diversity indices are as under:

Margalef's richness index (1958)

$$
d=(S-1) / \log _{e} N
$$

Where $\mathrm{d}=$ Margalef's richness index

$\mathrm{S}=$ Number of species

$\mathrm{N}=$ total number of individuals

Shannon-Wiener diversity index (1949)

$$
(H)=-\sum_{i=1}^{n} \text { pi log pi }
$$

$\mathrm{H}_{\max }=\log _{2} \mathrm{~S}$

$\mathrm{E}=\mathrm{H} / \mathrm{H}_{\max }($ Evenness $)$

$\mathrm{D}=1-\mathrm{E}$ (Dominance)

Where, pi is the proportion within the sample of the number of individuals of " $i$ th" species and is denoted as $\frac{n i}{N}$. $\mathrm{ni}=$ Number of " $\mathrm{i}$ "t" individual

$\mathrm{N}=$ Total number of individuals

$\mathrm{S}=$ Number of species or species richness

$\mathrm{H}_{\max }=$ Maximum of possible diversity

$\mathrm{E}=$ Evenness $=\mathrm{H} / \mathrm{H}_{\max }$

Simpson's diversity index (1949)

Simpson's dominance index of diversity (D):

$$
\operatorname{Diversity}(\mathrm{D})=(\mathrm{n} / \mathrm{N})^{2}
$$

Where, $\mathrm{n}=$ number of individuals or amount of each species

$\mathrm{N}=$ total number of individuals for the site

Species evenness (J) (1966)

$$
J=\frac{H}{\log _{e} S}
$$

Where, $\mathrm{H}=$ Shannon-Wiener biodiversity index $\mathrm{S}=$ number of species in the community.

\subsection{Statistical analysis}

All statistical analysis was performed using SPSS Statistical software (Version 20) and MS excel 2007.

\section{RESULTS AND DISCUSSION}

The results indicate rich pest diversity on walnut trees at different study sites with an overall of 10 insect species, belonging to 3 orders and 7 families. Out of 10 insect species reported, 8 were major or minor pests while 2 were predatory beetles feeding on aphids. Detailed report on pests, affected plant part and damaging stage in the life cycle of an insect pest is tabulated in Table 1.

\subsection{Walnut blue butterfly (Chaetoprocta odata (Hewitson 1865))}

Commonly called as walnut blue butterfly, $C$. odata is serious monophagous pest of walnuts, defoliating leaves and damaging sprouting buds. Larvae fed on the leaves, pest infestation started from March to May. Adults emerged in June and July, mostly feeding on nectar of flowers of nearby vegetation. Larvae were cylindrical in shape, light green in colour and with each instar development, the colouration changed from light green to dark green finally to dark brown in last instar. Each larval instar's strong mandibles nibbled irregular holes on leaves and also crawled to the emerging buds for feeding. Out of the different larval instars which were feeding voraciously on leaves, second instar was observed to be most damaging. It usually lays eggs on walnut twigs at the end of summer while these overwintering eggs coincide with the sprouting buds and hatch out in next season in March (Figure $1 \mathrm{a}-\mathrm{b}$ ). Khan et al., (2013) stated C. odata as most serious damaging lepidopteron pest infesting walnut trees. They revealed that the pest causes defoliation and damage to sprouting buds affecting both young and old walnut trees. Further, similar results were found by Abbas et al., (2015) in C. odata. They described the species as monophagous, having peak season from March to April with only one generation per year. 
Shaziya GULL et al.

Table 1: Diversity, period of activity \& feeding of insect pests on walnut plantation in Central Kashmir

\begin{tabular}{|c|c|c|c|c|c|c|c|}
\hline $\begin{array}{l}\text { Name of } \\
\text { insects } \\
\text { collected }\end{array}$ & $\begin{array}{l}\text { Scientific } \\
\text { name }\end{array}$ & Order & Family & $\begin{array}{l}\text { Collected } \\
\text { plant part }\end{array}$ & $\begin{array}{l}\text { Activity } \\
\text { period }\end{array}$ & $\begin{array}{l}\text { Feeding } \\
\text { on }\end{array}$ & $\begin{array}{l}\text { Feeding } \\
\text { stage }\end{array}$ \\
\hline $\begin{array}{l}\text { Walnut } \\
\text { aphid }\end{array}$ & $\begin{array}{l}\text { Chromaphis } \\
\text { juglandicola }\end{array}$ & Hemiptera & Aphididae & Leaves & Apr-Oct & Sap & $\begin{array}{l}\text { Nymph and } \\
\text { Adult }\end{array}$ \\
\hline $\begin{array}{l}\text { Duskey } \\
\text { veined } \\
\text { aphid }\end{array}$ & $\begin{array}{l}\text { Panaphis } \\
\text { juglandis }\end{array}$ & Hemiptera & Aphididae & Leaves & Apr-Oct & Sap & $\begin{array}{l}\text { Nymph and } \\
\text { Adult }\end{array}$ \\
\hline $\begin{array}{l}\text { Capsid } \\
\text { bug }\end{array}$ & $\begin{array}{l}\text { Megacoelum } \\
\text { stramineum }\end{array}$ & Hemiptera & Miridae & Leaves & Apr-Oct & Sap & $\begin{array}{l}\text { Nymph and } \\
\text { Adult }\end{array}$ \\
\hline Stink bug & $\begin{array}{l}\text { Apodiphus } \\
\text { pilipes }\end{array}$ & Hemiptera & Pentatomidae & Leaves & May-Sep & Sap & $\begin{array}{l}\text { Nymph and } \\
\text { Adult }\end{array}$ \\
\hline Lace bug & $\begin{array}{l}\text { Paracopium } \\
\text { cingalensis }\end{array}$ & Hemiptera & Tingidae & leaves & Apr-Oct & Sap & $\begin{array}{l}\text { Nymph and } \\
\text { Adult }\end{array}$ \\
\hline $\begin{array}{l}\text { Walnut } \\
\text { blue } \\
\text { butterfly }\end{array}$ & $\begin{array}{c}\text { Chaetoprocta } \\
\text { odata }\end{array}$ & Lepidoptera & Lycaenidae & Leaves & Mar-Jul & $\begin{array}{c}\text { Foliage \& } \\
\text { young } \\
\text { buds }\end{array}$ & Larvae \\
\hline $\begin{array}{l}\text { Asian } \\
\text { walnut } \\
\text { moth }\end{array}$ & $\begin{array}{l}\text { Ershoviella } \\
\text { musculana }\end{array}$ & Lepidoptera & Nolidae & $\begin{array}{l}\text { Nuts } \\
\text { young } \\
\text { shoots }\end{array}$ & May-Aug & $\begin{array}{c}\text { Nuts \& } \\
\text { young } \\
\text { buds }\end{array}$ & Larvae \\
\hline $\begin{array}{l}\text { Grey } \\
\text { weevil }\end{array}$ & $\begin{array}{l}\text { Myllocerus } \\
\text { spp. }\end{array}$ & Coleoptera & Curculionidae & Leaves & Apr-Sep & Foliage & $\begin{array}{l}\text { Larvae and } \\
\text { Adult }\end{array}$ \\
\hline $\begin{array}{l}\text { Ladybird } \\
\text { beetle }\end{array}$ & $\begin{array}{c}\text { Calvia } \\
\text { punctata }\end{array}$ & Coleoptera & Coccinellidae & Leaves & Apr-Sep & Aphids & $\begin{array}{l}\text { Larvae and } \\
\text { Adult }\end{array}$ \\
\hline $\begin{array}{l}\text { Ladybird } \\
\text { beetle }\end{array}$ & $\begin{array}{c}\text { Oenopia } \\
\text { conglobata }\end{array}$ & Coleoptera & Coccinellidae & Leaves & May-Aug & Aphids & $\begin{array}{l}\text { Larvae and } \\
\text { Adult }\end{array}$ \\
\hline
\end{tabular}

\subsection{Walnut Asian moth (Ershoviella musculana, Erschoff, 1874)}

One of the most important walnut pests, E. musculana feeds voraciously inside nuts and young shoots, leading to early nut drop and also consumes pericarp, resulting in deformed nut. In May, adults emerge and eggs are laid on the surface of young nuts. After hatching, it was observed that caterpillars pierce the nuts through petiole and start feeding inside. Single nut was pragmatic to have 2-3 larvae feeding inside during the study period. The larval instars were seen feeding on nuts from May to August. Newly hatched larva was creamy- white in colour, about 2-3 $\mathrm{mm}$ in size with dark brown head with long light hairs on pronotum while the size of each larval instar increases with increase in feeding capacity. The last instar was about $15-20 \mathrm{~mm}$ in size with few light brownish- cream hairs on dark brown scutella with light brown coloured body. In August, they start leaving nuts for pupation to continue life cycle next year. The pupation took place inside the loose bark or crevices of walnut trees. The infested nuts had deposition of excrement on the walnut husk which turns to brown \& it conversely reduces the yield and market value. Adults were not found damaging walnuts as they mainly fed on flower nectar and hovered on nearby vegetation (Figure $1 \mathrm{c}-\mathrm{d})$. The present study was in agreement with the work of Anonymous (2005) who stated E. musculana as an important walnut pest of fruit and young shoots, resulting in the formation of deformed nuts which leads to annual loss of about $70-80 \%$. Khan (2011) reported the pest for the first time from SKAUST, Shalimar, Srinagar, and J\&K. The nature, damage and biology of the studied pest confirm our results. 


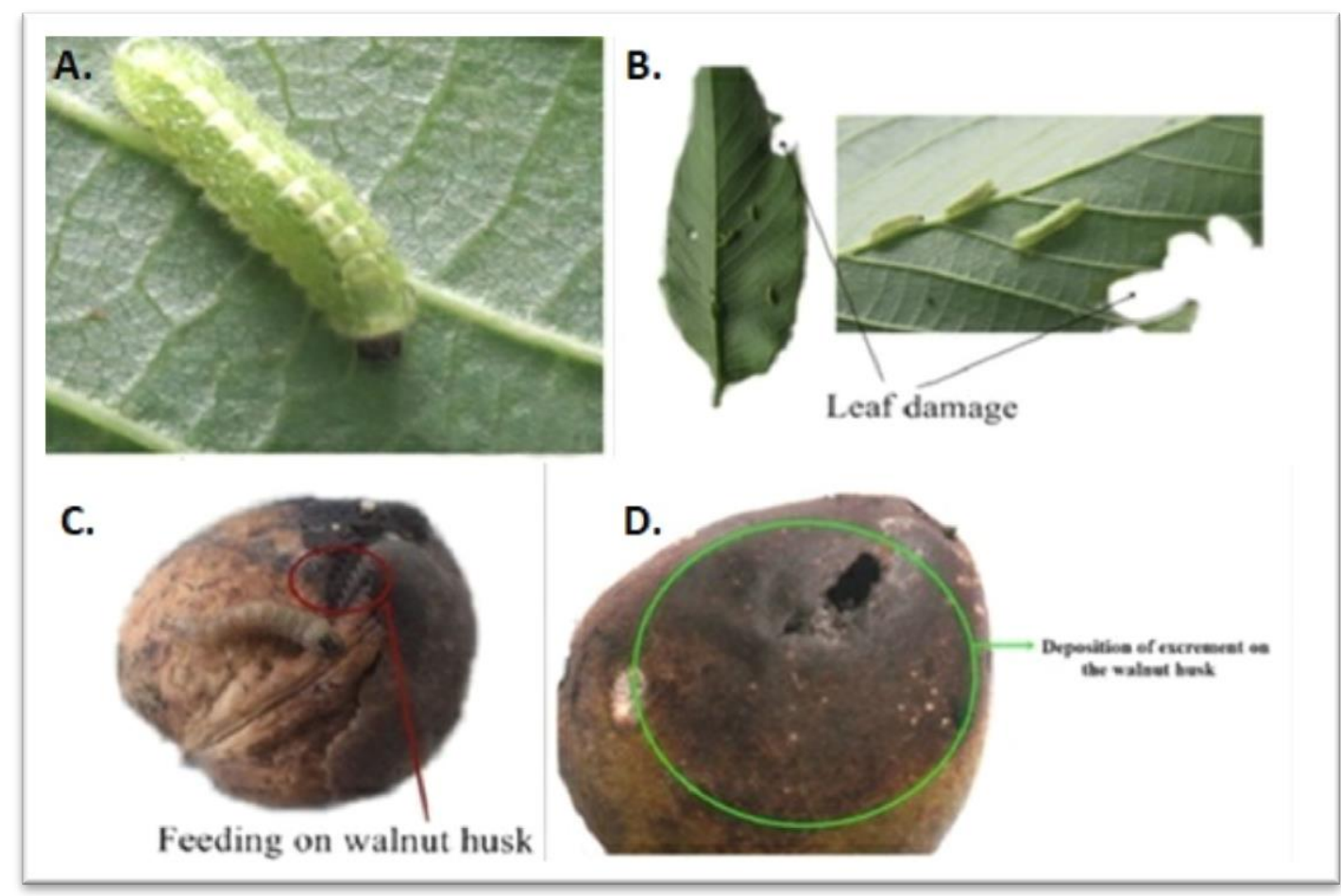

Figure 1: Larvae of C. odata and E.musculana

A: Damage caused by $C$. odata

B: Larva of $C$. odata feeding on walnut leaf

C: Larva of E.musculana feeding on walnut husk

D: Damage caused by E.musculana larva

\subsection{Aphids; (Chromaphis juglandicola Kaltenbach,} 1843) \& Panaphis juglandis (Goeze, 1778)

Two aphid species, Chromaphis juglandicola and Panaphis juglandis, were determined on the studied walnut trees. Infestation due to $C$. juglandicola was very high. Both species are sap suckers and are serious pests, feeding on phloem while the infestation started from April to October with peak infestation in June. The distribution pattern on leaves was also different, $C$. juglandicola was found scattered on the underside of leaves while $P$. juglandis was present on the upper side of leaves, feeding primarily near the mid rib of leaves. Further, $P$. juglandis was observed as minor pest in comparison to $C$. juglandicola. High population of walnut aphids lead to leaf drop, reduced tree vigour, nut quality and size besides shriveling of kernels. Both aphids develop parthenogenetically as well, leading to increase in population densities and nutrient uptake. On the other hand, excretion of honey dew attracts black sooty mould fungus which reduces light penetration to leaves, make them black and cause sunburn to fruits and thereby, reducing market value of fruits.

During the study period, both aphid species maintained distance and never fed on same leaf, strongly reinforces the Gause's competition exclusive principle, which states that no two species having same ecological niche can coexist together. $C$. juglandicola and $P$. juglandis were never seen feeding on same leaf during the study period. C. juglandicola is important factor that limit the populations of $P$. juglandis, which can be attributed to the excretion of acidic honeydew. Both aphids overwinter as egg stage, hatch out in early spring and produce young ones without mating which lead to the production of many generations per year and resulting in the development of many colonies in summer season. In the case of dusky-veined aphid ( $P$. juglandis) winged males and wingless females appear in September and cause general blackening of leaves while walnut aphid (C. juglandicola) cause early leaf drop and reduced nut size. (Figure 2 e-h). During the present investigation it was observed there was high infestation of walnut aphid population per leaflet which showed close congruity with result of UCIPM (2011) who had evaluated population of walnut aphid beyond 15 aphids per leaflet can reduce nut yield in terms of quality and quantity. Our results are in line with the studies carried out by Ginzel (2010) who reported both these aphid species as a contributing factor for reduced tree vigour, nut size and yield. Our results were strongly reinforced by the finding of the Mosz (2002) who had found aphid damage on walnut trees in the spring and summer and consume cell contents of the leaves. 


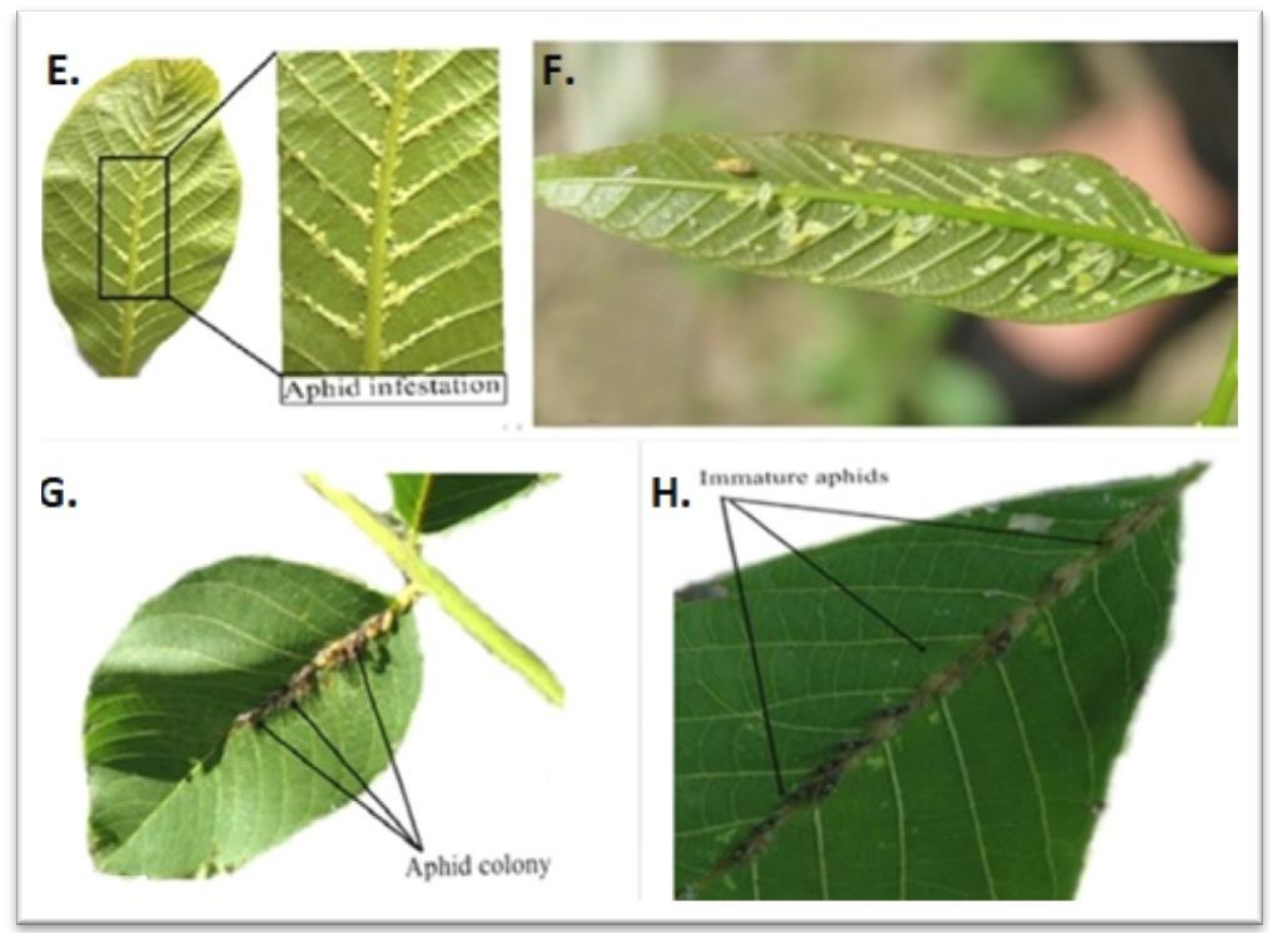

Figure 2: Adults and nymphs of $C$. juglandicola and $P$. juglandis

E: $C$. juglandicola scattered on lower surface of leaf

F: Adults and immatures of $C$. juglandicola feeding on lower surface of young leaf

G: $P$. juglandis feeding near mid rib of walnut leaf

H: Immature aphid colony feeding on mid rib of walnut leaf (upper surface)

\subsection{Stink bug (Apodiphus pilipes Horvath, 1889)}

Being a plant feeder, it sucks the sap of leaves from May to September. It has well developed rostrum which is inserted into the plant tissue for feeding (Figure 3i) while infestation is mainly on young developing buds and leaves. High infestation may cause stunted growth and sticky appearance. During the present study, it was observed that both adults and nymphs attacked walnut foliage notwithstanding, the population of A. pilipes was much weaker in comparison to other pests even though abundance was observed at few sites only. Less frequent appearance of the A. pilipes on walnuts can be attributed to apple trees as its prime host while acting as a visiting pest on walnuts owing to high competition in their own niche (Bhat, 2007).

\subsection{Lace bug (Paracopium cingalensis Walker, 1873)}

During the present study, it was found for the first time feeding on the sap of walnut tree leaves being active from April to October. Adults and nymphs were found to feed on the abaxial surface of leaves resulting in the formation of bumps. Being gregarious in nature they usually feed with protusible mouth parts on leaves making cholorotic patches resulting in development of galls on walnut leaves which leads to leaf drop, leaf discolouration and leaf blackening due to brownish black excrement deposited on them (Figure 3j). Our results are in line with the findings of McGavin (1993), Gull et al., (2018) and Deckert \& Scheiding (2006) whose findings revealed that tingids are exclusively herbivorous and feed on specific hosts causing damage to ornamental, friut and other crops, however such pests are more responsible for causing transmission of disease causing pests to plants.

\subsection{Capsid bug (Megacoelum stramineum Walker,1873)}

Megacoelum stramineum, commonly called as capsid bug, is a new report on walnuts as no data sets are available to confirm its feeding potential on walnuts although as per available literature, it has a wide host range. Adults usually feed on shoots, undersurface of walnut leaves from April to October (Figure 3k). The visible symptoms include small and round sunken spots on leaves while infestation appears from spring to early autumn with peak abundance in summer. The present results were reinforced by work of Udikeri et al., (2014) who carried out its damaging potential on crops. 


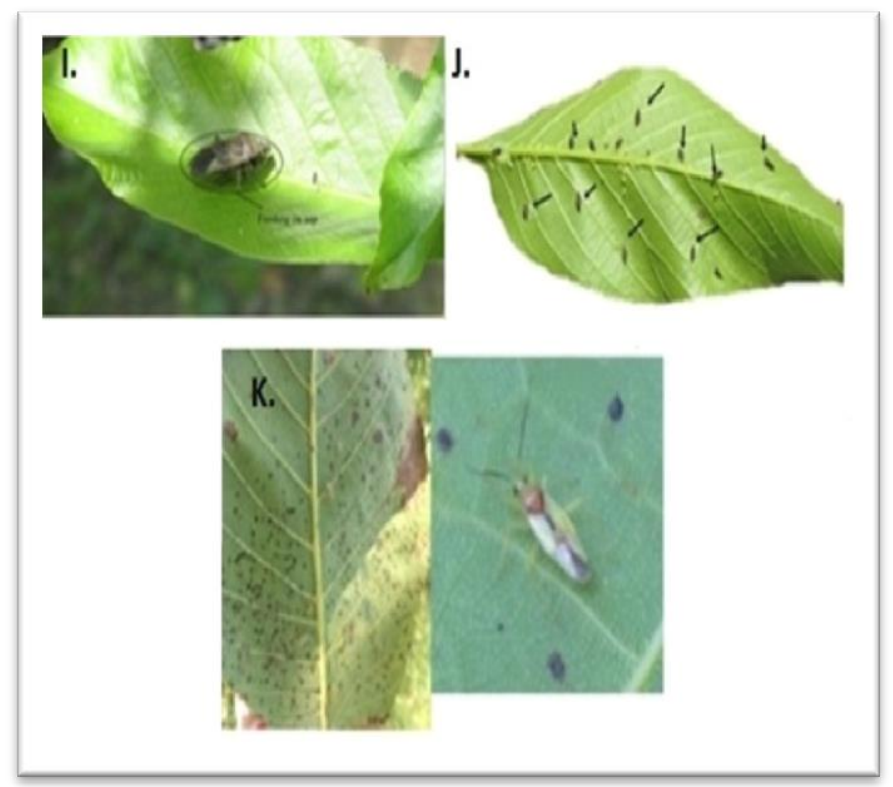

Figure 3: A. pilipes, $P$. cingalensis and $M$. stramineum feeding in walnut leaf sap I: A. pilipes feeding on the sap of walnut leaf $\mathbf{J}$ : $P$. cingalensis feeding on the sap of walnut leaves (Lower surface)

K: M. stramineum excreata along with black soot

\subsection{Grey weevil (Myllocerus spp.)}

It is commonly called as Grey weevil and is the most serious pest causing defoliation of trees by feeding on the leaf margins and is active from April to September. It nosh inwardly along the leaf veins, preferring new foliage and young shoots. During the present work, adults were serious defoliators while grubs were concealed feeders. Adults usually fed on leaves, making holes of $2-3 \mathrm{~cm}$ and then gradually eating up the entire leaf leaving behind mid rib only. Further, it curles the leaftips and are generally called as leaf rollers which leads to general blackening of the tips of leaves as was revealed by Mir \& Wani, (2005). (Figure 4 l-n).

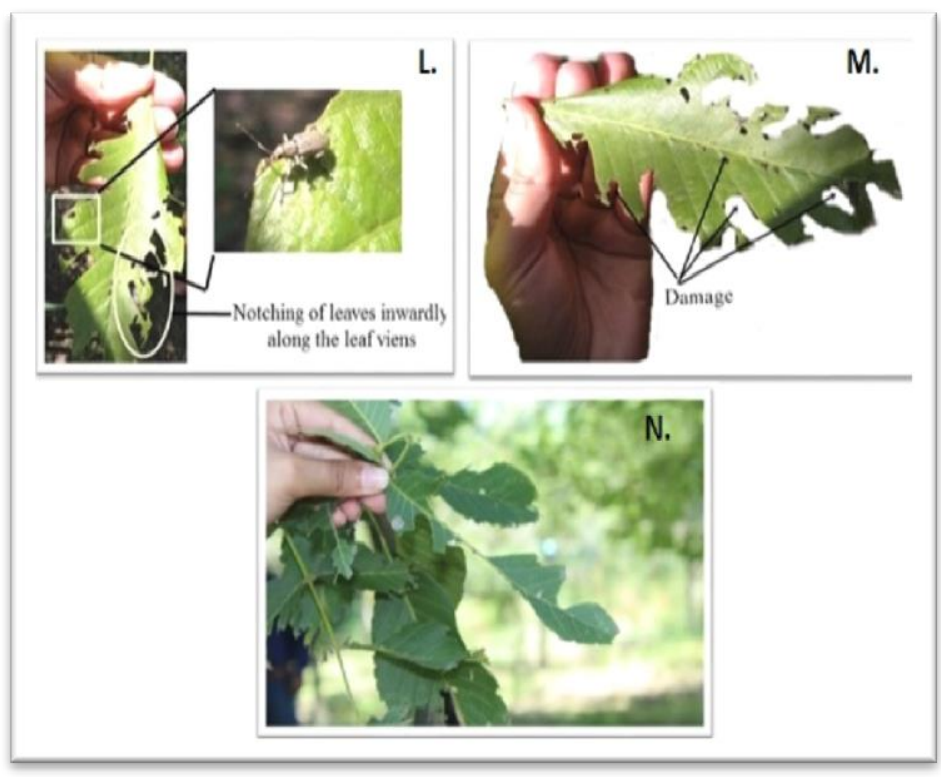

Figure 4: Feeding and damaging pattern shown by Myllocerus spp.

L: Myllocerus spp. feeding on foliage of walnut leaves.

M: Notching of leaves caused Myllocerus spp.

$\mathbf{N}$ : Damage caused by Myllocerus spp. leaving behind only mid rib 


\subsection{Diversity indices}

Diversity indices were studied in three districts of Central Kashmir viz., Srinagar (S), Budgam (B) and Ganderbal (G) with three sites chosen at each district such as S1, S2 and S3 for Srinagar, B1, B2 and B3 for district Budgam and G1, G2 and G3 for district Ganderbal. The insect pest community was analyzed for species diversity by applying Shannon- Weiner index which combines the effect of richness and evenness. The mean abundance of pests with significant differences is presented in Table 2. During the analyses, Shannon- Weiner index decreased with decrease in total number of species. On comparing the data of various sites of Central Kashmir, it was found that the diversity index in Srinagar showed the highest value at S3 (1.41), followed by S2 (1.25) \& S1 (1.10). In Budgam, peak value was recorded at B2 (1.57) followed by B1 (1.40) and B3 (1.31). In Ganderbal district, higher values were found at site G1 (1.31) followed by G2 (1.12) and G3 (1.00). The Simpson's diversity index did not show any noticeable variations among the study sites. However, the diversity index recorded the highest value in Srinagar at S1 (0.48) followed by S2 (0.41) and the lowest one at S3 (0.31). The diversity index fluctuated at Budgam from B3 (0.35) to B1 (0.32) and lower at B2 (0.24). However, In Ganderbal maximum value was found at G3 (0.44) followed by G2 (0.43) and G1 (0.36). The Margalef's diversity index was applied to measure the distribution pattern and richness of species at a particular site (Figures 5-7). According to the evaluated results, the insect heterogeneity was found different at different sites of Central Kashmir. The upper most range was found at S2 (7.69), followed by site S1 (5.43) and site S3 (5.36). At Budgam, peak value was at site B3 (5.53) with lower values at B2 (5.32) and least at B1 (4.96). However, minimum value of diversity was found at G3 (2.43) with maximum at G2 (6.51) and G1 (5.29) at Ganderbal (Figure 8x).

The Pielou's evenness index showed higher value at site S3 (0.79) followed by site S2 (0.64) and site S1 (0.62) in Srinagar. At Budgam evenness was found the highest at site B2 (0.87) followed by site B1 (0.78) and the lowest at site B3 (0.73). On comparing the evenness at three sites of Ganderbal, species were more evenly present at G1 (0.73) followed by site G3 $(0.72)$ and G2 (0.69) (Figures 5-7).

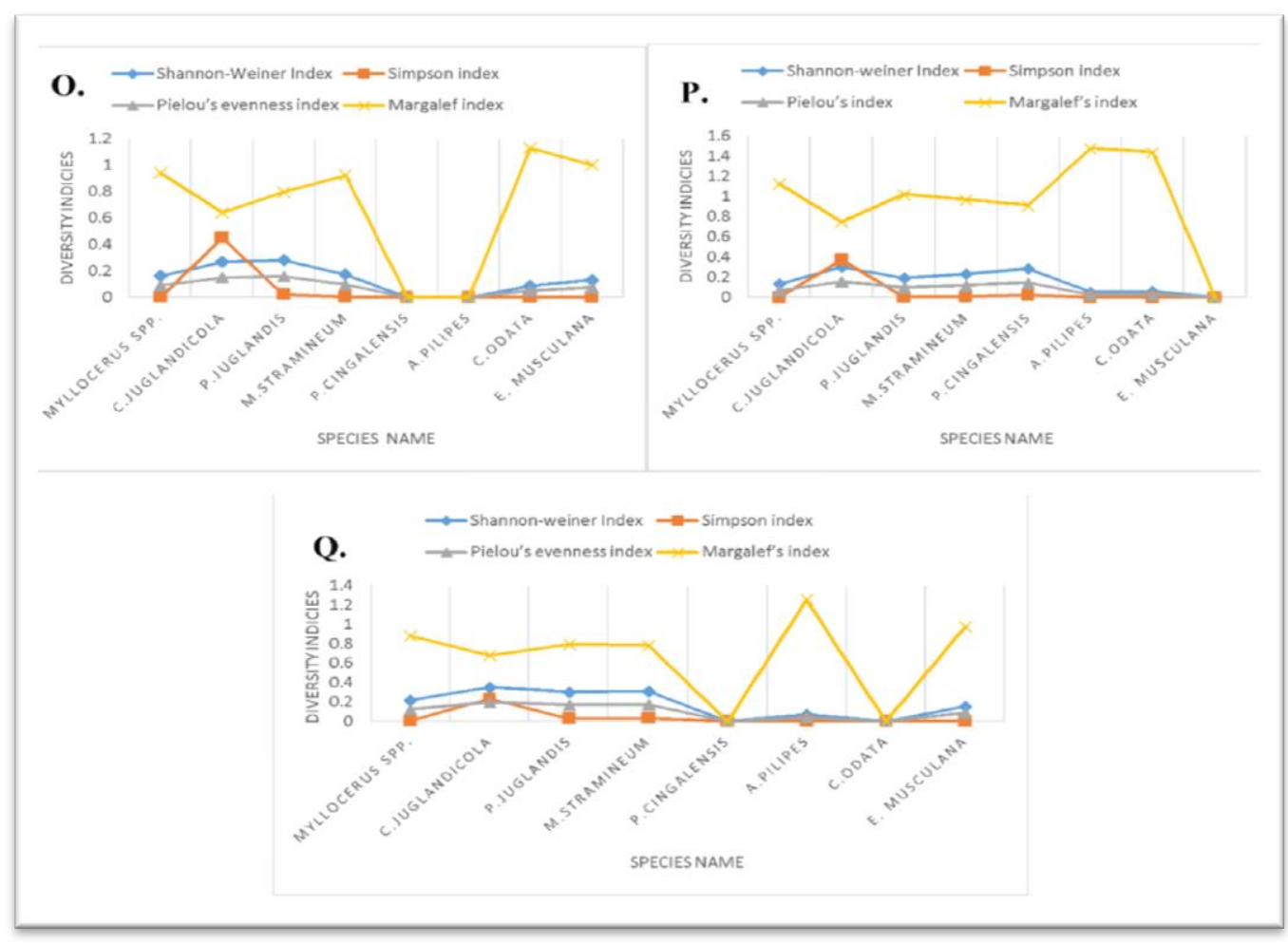

Figure 5: Diversity indices of various pest species of district Srinagar O: Distribution of pest in walnut orchard at site S1 of district Srinagar P: Distribution of pest in walnut orchard at site S2 of district Srinagar Q: Distribution of pest in walnut orchard at site S3 of district Srinagar 


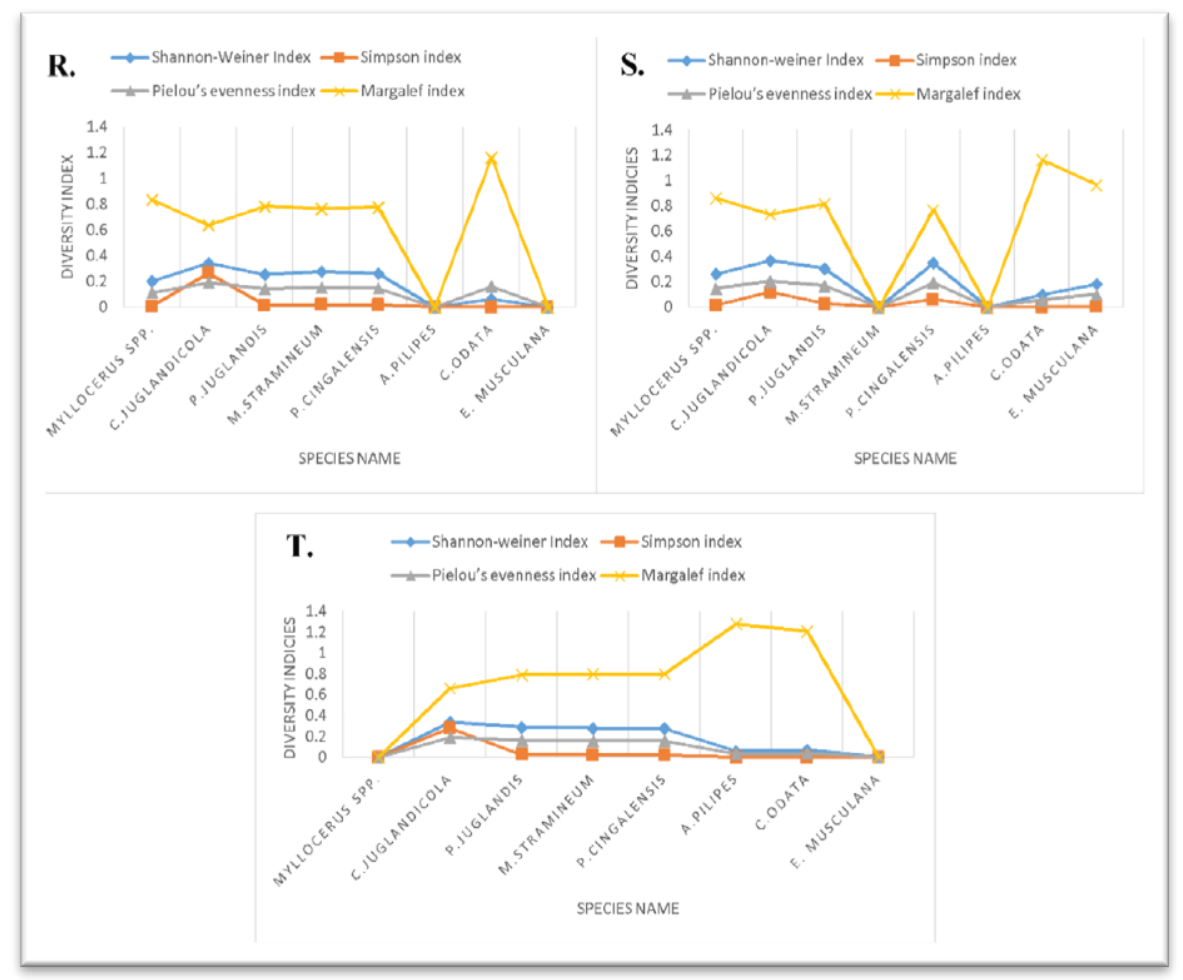

Figure 6: Diversity indices of various pest species of district Budgam R: Distribution of pest in walnut orchard at site B1 of district Budgam S: Distribution of pest in walnut orchard at site B2 of district Budgam T: Distribution of pest in walnut orchard at site B3 of district Budgam

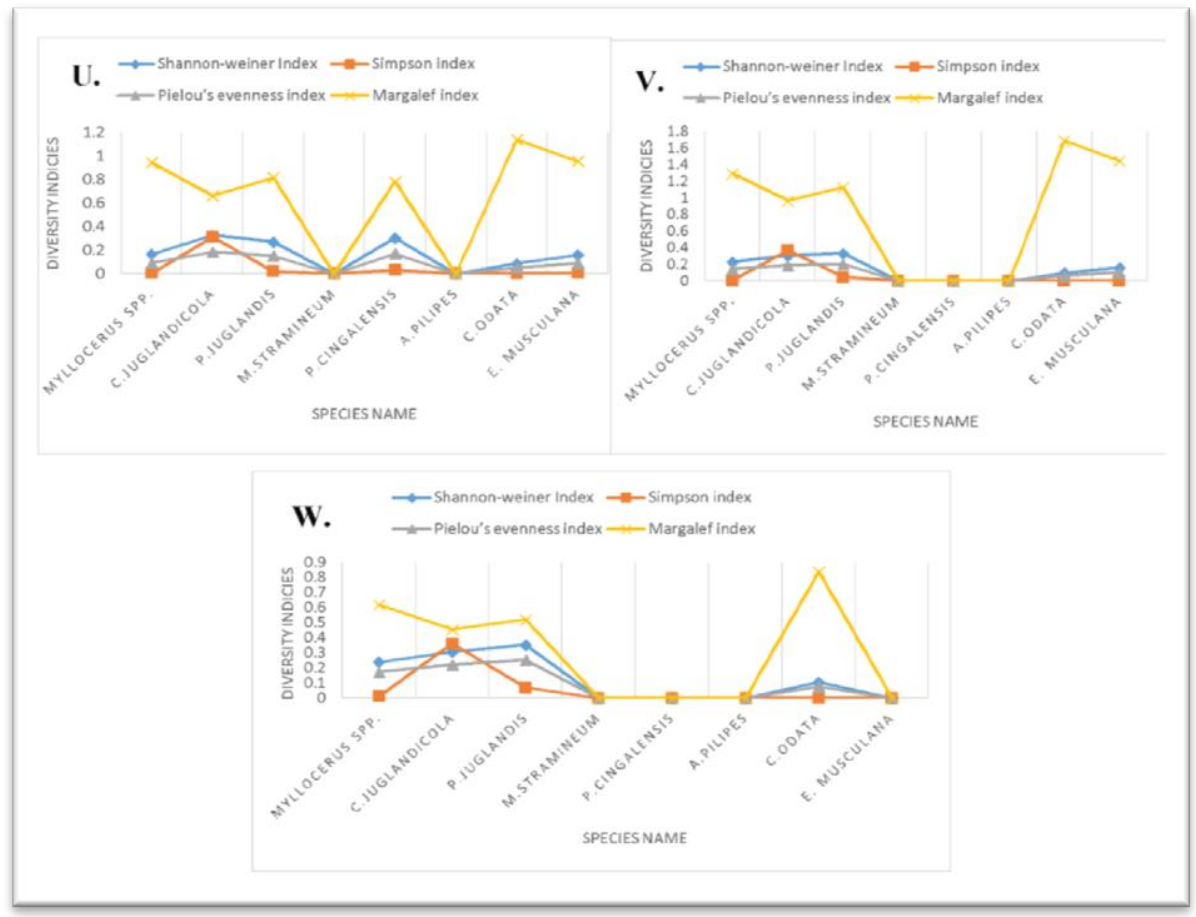

Figure 7: Diversity indices of various pest species of district Ganderbal U: Distribution of pest in walnut orchard at site G1 of district Ganderbal V: Distribution of pest in walnut orchard at site G2 of district Ganderbal W: Distribution of pest in walnut orchard at site G3 of district Ganderbal 


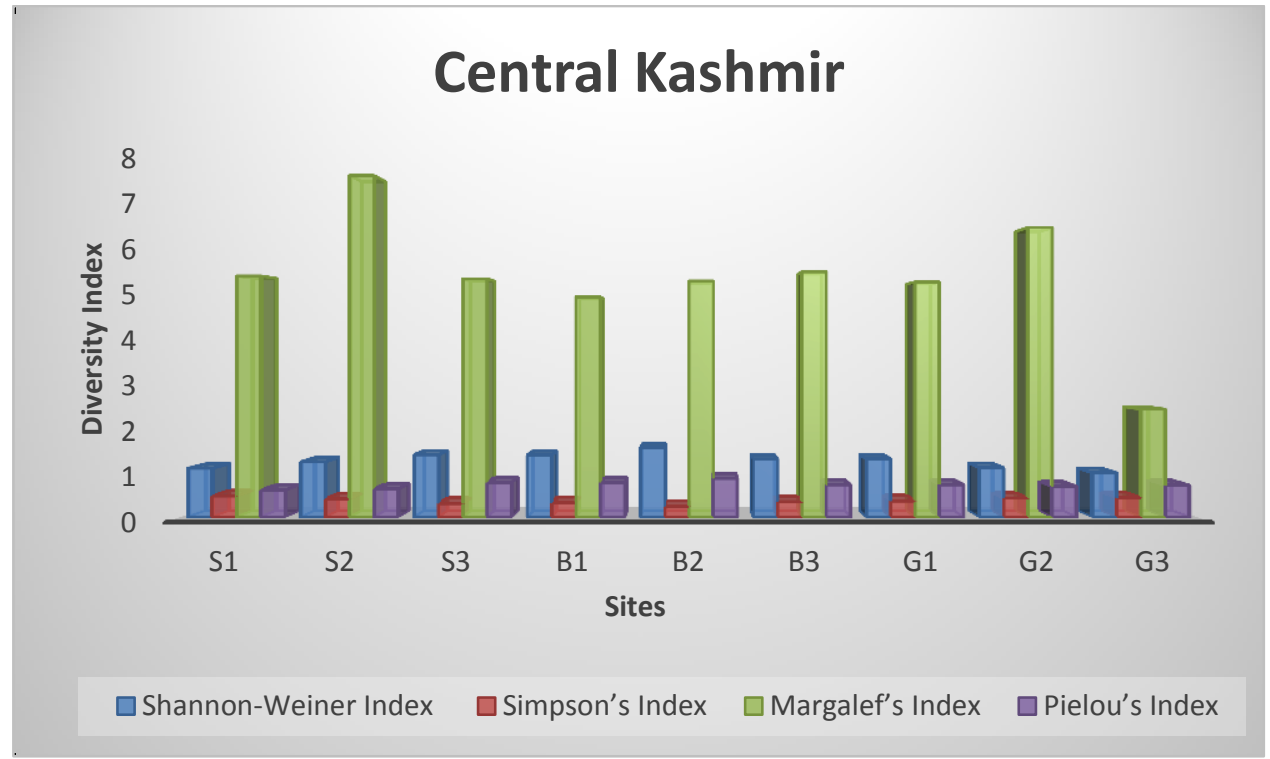

Figure 8X: Various diversity indices of insect orders infesting walnut orchards at different sites of Central Kashmir

The overall average diversity of pests infesting walnut orchards of Central Kashmir depicted that ShannonWeiner diversity index (H) was utmost at Budgam (1.43) and least at Srinagar (1.25). However, Simpson's diversity index (D) was higher at Ganderbal (0.41) and lower at Budgam (0.30). Margalef's diversity index (MI) had uppermost value at Srinagar (6.16) and lowermost at Ganderbal (4.74) while as Pielou's index depicted the evenness values having higher values at Budgam (0.80) and lower at Srinagar (0.68) (Figure 8y).

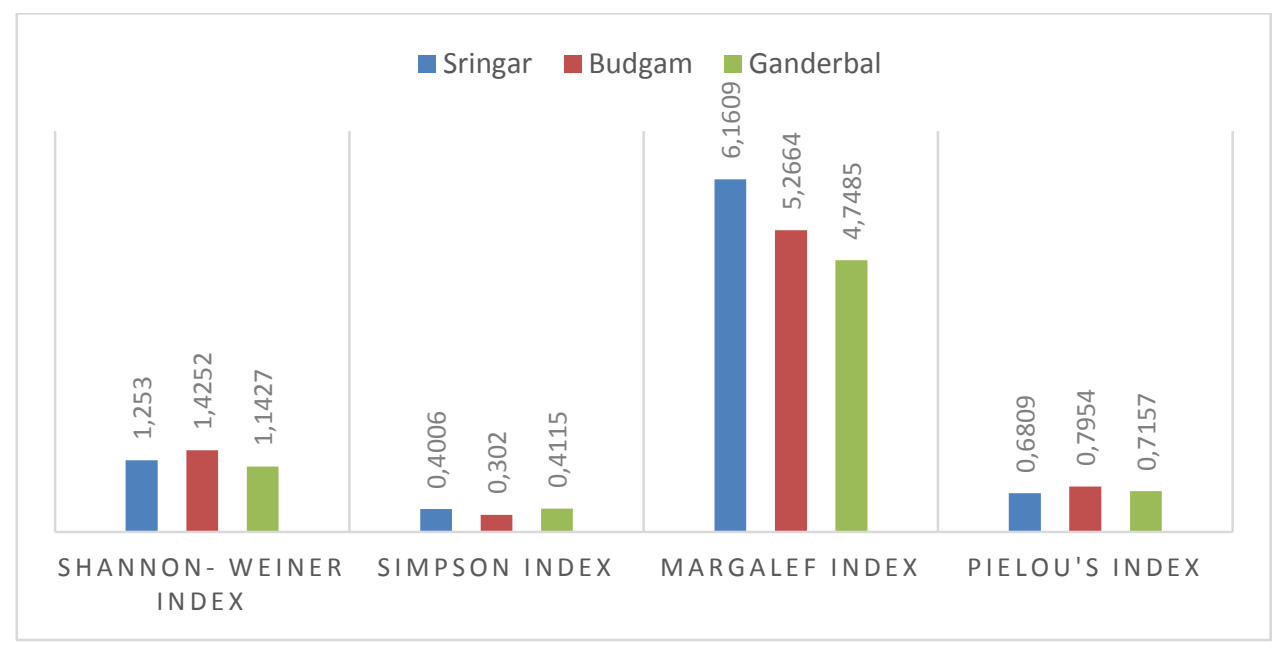

Figure 8Y: Average values of diversity indices in different districts of Central Kashmir 
Table 2: Mean of pest abundance in Srinagar, Budgam \& Ganderbal districts, Jun 2014- Nov, 2015.

\begin{tabular}{lccc}
\hline Species & Srinagar & Budgam & Ganderbal \\
\hline C. juglandicola & $225.23 \pm 141.63^{\mathrm{b}}$ & $169.00 \pm 128.09^{\mathrm{ab}}$ & $135.07 \pm 91.36^{\mathrm{a}}$ \\
P. juglandis & $46.32 \pm 38.86^{\mathrm{a}}$ & $49.06 \pm 35.56^{\mathrm{a}}$ & $39.91 \pm 31.50^{\mathrm{a}}$ \\
Myllocerus spp. & $26.19 \pm 11.46^{\mathrm{a}}$ & $38.83 \pm 20.16^{\mathrm{b}}$ & $21.35 \pm 12.08^{\mathrm{a}}$ \\
P. cingalensis & $66.36 \pm 34.95^{\mathrm{a}}$ & $56.63 \pm 29.34^{\mathrm{a}}$ & $65.78 \pm 30.00^{\mathrm{a}}$ \\
C. odata & $10.64 \pm 5.71^{\mathrm{a}}$ & $10.50 \pm 7.36^{\mathrm{a}}$ & $8.57 \pm 6.49^{\mathrm{a}}$ \\
E. musculana & $22.57 \pm 3.39^{\mathrm{a}}$ & $25.14 \pm 2.54^{\mathrm{a}}$ & $22.50 \pm 5.72^{\mathrm{a}}$ \\
\hline
\end{tabular}

Significant $p<0.05$, Non-significant $p>0.05$; Mean values with different superscripts are significantly different $(p<0.05$, Tukeys HSD)

The aim of the present study was to focus on the different walnut insect pests which reduce the yield of walnuts and directly influences the people who are involved in the commercial trading system at national level. Any manipulation in the plant communities by the human activities results in the more susceptible insect pest attack (Altieri 1991). A total of 8 insect pests were collected belonging to three insect orders, i.e. Coleoptera, Hemiptera and Lepidoptera were recorded on the walnut trees of Central Kashmir. Mir \& Wani (2005), Khan et al. (2011, 2013) mentioned most of the species on walnut, which were recorded during present investigation. However, newly recorded two pest species, i.e. Paracopium cingalensis and Megacoelum stramineum were for the first time recorded on walnuts of Central Kashmir. UCIPM in 2011 reported about 17 species of arthropod infesting walnuts. Ginzel (2010) mentioned about at least 10 species infesting walnut and studied their activities as pest. Diversity of insects enables us to understand the relationship between the habitat and ecosystem (Denys \& Tschantke 2002). The results revealed that each site varied in the species diversity, species richness and evenness prevailing on walnut ecosystem. The result depicted that all the sites of three districts of Central Kashmir had similar diversity levels as reported in Shannon-Wiener diversity index, Pielous's index, Margalef's index and Simpson index. However, each site at three districts of Central Kashmir had different values when examined with the four measures of diversity. This variation observed in the pests infesting walnut reflects that there is variation in the distribution and abundance of pests infesting walnut. Perfecto et al., (1997) have also observed that natural and unobserved habitats have significant impact on insect diversity within heterogeneous environment.
Shannon - Weiner diversity index was used to calculate the diversity of each site of Central Kashmir which included three districts viz., Srinagar, Budgam and Ganderbal. It was found to be $1.25,1.43$ and 1.14 indicating sites of Central Kashmir were more or less similarly diversified. This was in line with the findings of Chakraborty (2014). Simpson's index $(\lambda)$ gives the probability that two individuals, when selected at random from population, belong to particular species (Ambrose 2004). Higher the value less is the dominance of each species prevailing in a particular community. Our results showed 0.40, 0.30, and 0.41 for Srinagar, Budgam and Ganderbal respectively which shows all sites of Central Kashmir have more or less equal diversity index. Higher values may indicate a healthy environment for insects. The values calculated for districts Srinagar (6.16), Bugdam (5.27) and Ganderbal (4.74) portrayed that Srinagar had high value for species richness and it may be attributed to the presence of higher number of species infesting untreated walnut trees and forms good ecosystem for higher diversity. According to Hart \& Horwitz (1991) the habitat heterogeneity simply has more number of arthropod species where different types of plant species are found. Various factors such as resource availability for both adults and larva plays significant role in increasing the richness of particular area as observed by Pinheiro \& Ortiz (1992). One possible explanation for direct correlation between the food plant and richness of species associated to it could be potentially due to higher number of niches associated to plant which exists within there (Hutchinson, 1959). Species richness provides an advantageous measure of diversity when total number of species in the community is obtained (Magurran, 1988). In the present study evenness ranged from 0 to 1 which signifies that scale ranging from near 
0 , indicates low evenness or high single specie dominance, to 1 which indicates abundance of all species or maximum evenness (Routledge, 1980). Pielous's index was high at Ganderbal (0.72) which indicated that the species are more evenly distributed there.

Many researchers have studied the diversity of insects and their association and interactions with the plant community. Panzer \& Schwartz (1998) investigated that $49 \%$ of variance in insect species is due to plant species richness among the studied areas. The present study revealed the decrease in diversity count from season to season and site to site can be attributed to low availability of food resources, which was previously reported by Thomazini \& Thomazini (2002). Phylogenetic diversity (May, 1990) and endemism (Jetz et al., 2004) also influence variation of species diversity. Other factors which influence the diversity is competition, succession and the most important predation which causes the change in species evenness without change in richness (Tramer Elliot, 1969; Magurran, 1988). The indices values of the present study were in close proximity with the findings of Reddy \& Moos (2015) on calculating insect diversity, species richness and evenness of the walking mango tree with $\mathrm{H}=1.417, \mathrm{D}=0.306, \mathrm{MI}=8.17$ and $\mathrm{Mh}$ $=5.435$. Our results were strongly reinforced by the findings of Abbas et al. (2015) who found the biodiversity and dynamics of macro-invertebrate population in wheat weeds in agro-ecosystem and recorded diversity $(H=3.36)$ and evenness $=0.402$ when Species richness $(S)=72$, however when $S=58$, diversity $(H=3.23)$ and evenness $(E=0.79)$ on wheat. Thus, it can be concluded that when species richness decreases the value of $\mathrm{H}$ decreases and $\mathrm{E}$ increases and was in conformity with our result.

In the present study order Hemiptera was the predominant order and comprised about $89 \%$ of the pests infesting walnut. Similar results were found by Rajadurai \& Thiagarajan (2003) who reported 18 heteropterans and 10 homopterans infesting mulberry and found it dominant order causing high infestation. During the pest investigation each season showed fluctuations in the total species richness and abundance, pest activity was high during spring and summer. On set of autumn there was reduced pest load as there was sharp decline in the abundance of pests and in winter no pest diversity was observed. Similar result was found by Kutschbach- Brohl et al., (2010). Seasonal fluctuations can be explained as all the insect species have different phenologies and resulted difference in activity periods is depending on temperature (Booij, 1995). The present study also correlates with the findings of Daiqin \& Jackson (1996) and Finch et al., (2008). The change in diversity index values is attributed to rainfall and other environmental factors. Cartea et al. (2009) found the similar results when studied the lepidopteron pest population infesting Brassica in Spain for six years and concluded that environment is directly correlated with pest population. Presence of food is one of the important factors for maintenance of diversity in a particular ecosystem. This is strongly reinforced by the findings of Perrins et al. (1991) who concluded that the presence of any species is restricted by the distribution of its habitat and within that habitat there must be enough food availability and other resources so that species exists. The predominant natural enemies were ladybird beetles however, population was not much pronounced. Manjunath et al. (1989) also reported that parasites and predators are inadequate to check pest build up thus, management strategies are very essential to check further losses. Species richness and abundance are both essential aspects for the structure of community. Several studies have concluded the community structure can be changed with the change in the relative abundance of species even when species richness remains the same (Magurran, 1988; Stirling \& Wilsey, 2001).

\section{CONCLUSION}

Walnut industry is one of the prime industries of Kashmir with over $90 \%$ of its demand in the country met by Kashmir only. Nonetheless unlike apples, this sector is yet to flourish at international market due to various factors and non-seriousness of government as well as other stake holders notwithstanding, the importance is quintessential for its existential threat. In this backdrop, this piece of research work has been conducted to check its current status and insect pest diversity with their overall effect on quality and quantity of walnuts. A total of nine sites were selected from three different districts and the insects pests collected belonged to 3 orders 7 families and 10 species. The abundance of pests infesting walnut orchards showed the same seasonal pattern with increase in spring, reaching maximum in summer and then decreasing in autumn. A wide range of abundance (4944 individuals at site B1 of the district Budgam to 1207 individuals at site $\mathrm{G} 3$ of the district Ganderbal) and number of species (7 at site S1 to 4 at site G3 of the district Ganderbal) clearly demonstrated that there are slight differences amongst these sites in the prevailing factors that affect pest community. Most of the sites had consistent number of the pests collected during the study period. The study also depicted that order Hemiptera was highly damaging in comparison to Coleoptera and Lepidoptera 
while in Hemiptera, the strongest damage was done by C. juglandicola and the weakest one by A. pilipes (Figure 8z). Observations of these sites did not reveal any major changes in habitat between the study period of one and half year. Diversity indices, i.e. ShannonWeiner index, Simpson index, Pielou's index and
Margalef's index varied in different sites and time of the year, which is attributed to the change in quality and quantity of food as well as temperature fluctuations. The work represented here would be very helpful in controlling the walnut pests in different seasons to yield better quality and quantities of walnut in Kashmir.

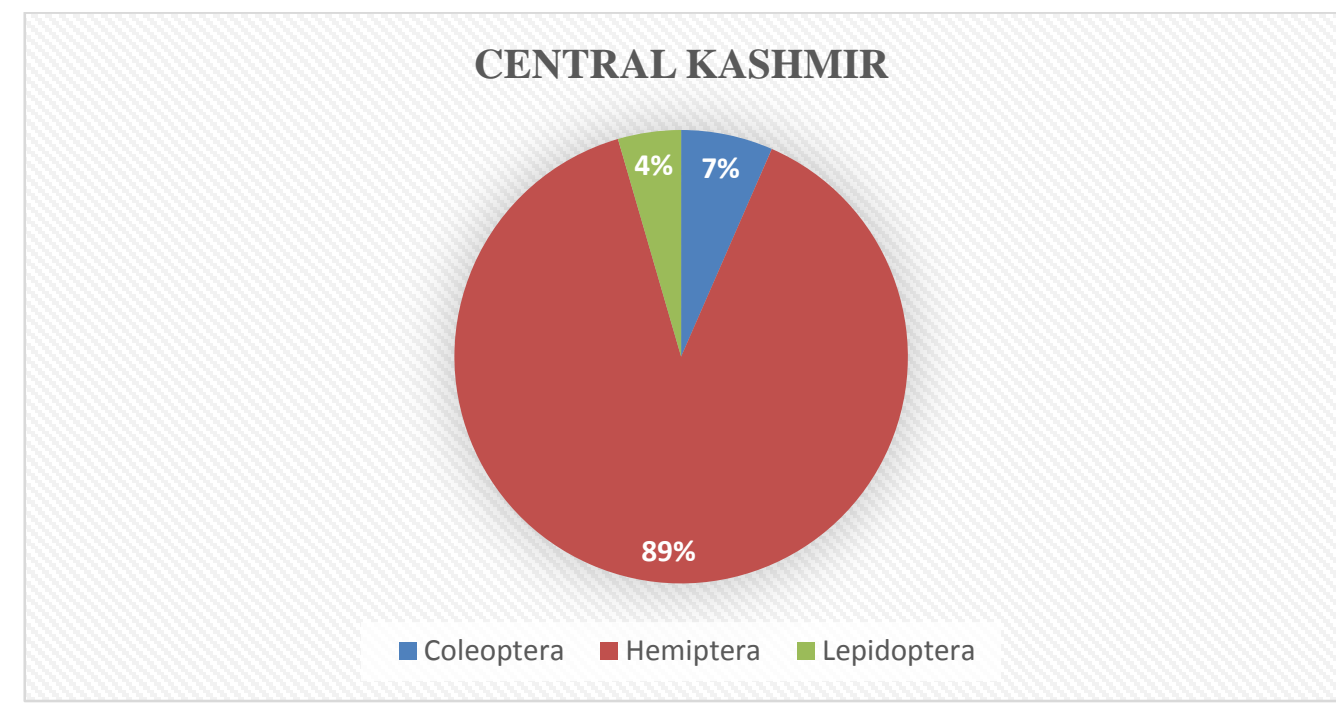

Figure 8Z: Overall composition of insect orders infesting walnut orchards in Central Kashmir (\%).

\section{ACKNOWLEDGEMENT}

We are grateful to the Head, Department of Zoology, University of Kashmir for providing working facilities. Besides, authors are highly indebted to Dr. M. E. Hassan, Scientist- D and I/C Hemiptera Section, Zoological Survey of India (ZSI), Kolkata for his cordial help in the identification of specimens and necessary follow-up. Authors are highly thankful to Mr. Mushtaq Ganai for his cordial help in statistical analysis. There is no conflict of interest among the authors for publishing this manuscript.

\section{REFERENCES}

Abbas, A., Wani, N.A., Ahmad, S.B., Wani, A.R., \& Munib, M. (2015). Incidence and relative bioefficacy of different insecticides against Chaetoprocta (Chaetoprocta odata Hewitson) infesting walnut in Kashmir Valley. Journal of Agricultural Science, $7(9), \quad 212-219$. https://doi.org/10.5539/jas.v7n9p212

Anonymous. (2005). Data sheet on quarantine pests Erschoviella musculana. European and Mediterranean Plant Protection Organization Bulletin, 35, 425-428.

Ahmed, N., \& Ahmed, T. (2013). Fruit related problem and their management in Rajouri district of Jammu \& Kashmir. Journal of Humanities and Social Sciences, 12(2), 65-75.
Altieri, M.A. (1991). Increasing biodiversity to improve insect pest management in agroecosystems. In "The Biodiversity of Microorganisms and Invertebrates: Its role in sustainable Agriculture". Cd. D. L. Hawksworth, CAB International, (Walling ford, UK), 165-182 pp.

Ambrose, D.P. (2004).The insects, structure, function and Biodiversity. Kalyani publishers, Chennai. 821 pp.

Bhagat, R.C. (1986). Aphid pests of fruit trees and their natural enemies in Kashmir Valleys, India. Indian Journal Agricultural Science, 56(7), 532-534.

Booij, C.J.H., Nijs, L. J.M.F., \& Noorlander, J. (1995). Spatiotemporal patterns in activity density of some carabid species in large scale arable fields. Acta Jutlandica, 70, 175-184. 
Boyce, A.M. (1934). Bionomics of the walnut husk fly, (Rhagoletis completa). Hilgardia, 8, 363-579. https://doi.org/10.3733/hilg.v08n11p363

Bhat, M.S. (2007). Taxonomic Survey and Bioecological studies of stink bugs (Heteroptera: Pentatomidae) of Kashmir. Ph.D. Thesis, University of Kashmir, 1-278pp

Cartea, M.E., Padilla, G., Vilar, M., \& Valesco, P. (2009). Incidence of major Brassica pests in Northwestern Spain. Economic Entomology, 767773. https://doi.org/10.1603/029.102.0238

Chakraborty, A., Kumar, K., \& Chitra, N. (2014). Computation of Insects biodiversity in Bhendi (Abelmoschus Esculentus (L.) Moench) ecosystem. An international quarterly Journal of life Sciences, 9(4), 1405-1409.

Daiqin, D.A., Jackson, J. (1996). How temperature affects development \& reproduction in spiders: a review. Journal of Thermal Biology, 21, 245-274. https://doi.org/10.1016/0306-4565(96)00009-5

Deckert, J., \& Scheiding, G.U. (2006). Lacebugs of Namibia (Heteroptera, Tingoidea, Tingidae). Landesmuseen Neue Serie, 823-856.

Denys, C., \& Tschantke, T. (2002). Plant- Insect communities and predator-prey ratios in field margin strips, adjacent crop fields, and fallows. Oecologia, 130, 315-324. https://doi.org/10.1007/s004420100796

Directorate of Horticulture. Tremendous turnover of walnuts in various districts of Kashmir valley. Greater Kashmir, 2015, 5pp Available from http:// www.greaterkashmir.com (Accessed on 5 October 2017)

Finch, O.D., Blick, T., \& Schuldt, A. (2008). Macroecological patterns of spiders, species richness across Europe. Biodiversity Conservation, 17, 2849-2868. https://doi.org/10.1007/s10531-0089400-x

Ginzel, M.D. (2010). Walnut insects: Ecology and control. Encyclopedia of Pest Management, 1(1), 13.

Gull, S., Ahmad,T., Rasool, A ., \& Rasheed, R. (2018). Assessment of damage and seasonal abundance of paracopium cingalensis (lace bug) (wal.) on Juglans regia (walnut) (lin.) in central Kashmir, India. Uttar Pradesh journal of Zoology, 38(3), 7483.

Hart, D.D., \& Horwitz, R.J. (1991). Habitat Diversity and the Species Area Relationship, Alternative Models and Tests. In Bell, S. S., Mc Coy, E. D. \& Mursshinshy, H. R.Eds. Habitat Structure: The
Physical Arrangement of Objects in Space, Chapman \& Hall, London, 47-68. https://doi.org/10.1007/978-94-011-3076-9_3

Hutchinson, G.E. (1959). Homage to Santa Rosalia, or why are there so many kinds of animals? Amercican Naturalist, 93, 145-159. https://doi.org/10.1086/282070

Jetz, W., Rahbek, C., \& Colwell, R.K. (2004). The coincidence of rarity and richness and the potential signature of history in centres of endemism. Ecology Letters, 7(12), 1180-1191. https://doi.org/10.1111/j.1461-0248.2004.00678.x

Khairmode, P.V., \& Sathe, T.V. (2014). Seasonal abundance of weevils Myllocerus spp. on mulberry in Kolhapur region. International Journal of Science, Environment and Technology, 3(1), 203207.

Khan, S.A., Bhatia, S., \& Tripathi, N. (2013). Entomological investigation on Aeolesthes sarta (Solsky), A major pest on walnut trees (Juglans Regia L.) in Kashmir Valley. Journal of Academia and Industrial Research, 2(6), 325-330.

Khan, Z.H., Ramamurthy, V.V., Dar, M. A., \& Raina, R. H. (2011). The Asian walnut North Erschoviella musculana Ershoff, 1874 (Nolidae: Lepidoptera) A new part of walnut for Kashmir Valley of J\&K, India. Indian Horticulture Journal, 1(1), 055-056.

Kumar, D., \& Naidu, B. (2010). A contribution towards the insect fauna of Vadodara, Gujrat (India): The Older Hemiptera. Hallteres, 1(2), 58-63.

Kutschbach-Brohl, L., Washburn, B.E., Bernhardt, G.E., Chipman, R.B., \& Francoeur, L.C. (2010). Arthopods of a semi-natural grassland in an environment: The John F. Kennedy International Airport, New York. Journal of Insect Conservation, 14, 347-358. https://doi.org/10.1007/s10841-0109264-8

Magurran, A.E. (1988). Ecological Diversity and its Measurement. Princeton University Press, Princeton, N.J., \& Schowalter, T.D. Ed. Insect Ecology. An Ecosystem Approach. Academic Press USA, 221-247. . https://doi.org/10.1007/978-94015-7358-0

Manjunath, T.M., Bhatnagar, V.S., Pawar, C.S., \& Sithanantham, S. (1989). Proc. Biological Control of Heliothis: Increasing the effectiveness of Natural Enemies.Eds. King, E.C and Jackson, R. D. USDA, New Delhi. pp. 197-228.

Martinez, M.L., Labuckas, D.O., Zhang, S., \& Nikaido, T. (2004). New alphatetralonylglucosides from the fruit of Juglans mandshurica. Chemical 
Pharmaceutical Bulletin, Tokyo, 52, 566-569. https://doi.org/10.1248/cpb.52.566

May, R.M. (1990). Taxonomy as destiny. Nature, 347, 129-130. https://doi.org/10.1038/347129a0

Mc Gavin, G. C. (1993). Bugs of the world. London. Blandford, an imprint of Cassell plc., $192 \mathrm{pp}$.

Mir, G.M., \& Wani, M.A. (2005). Severity of infestation and damage to walnut plantation by important insect pests in Kashmir. Indian Journal of Plant Protection, 33(2), 188-193.

Mohandas, S., Saravanan,Y., \& Manjunath, K. (2004). Biological control of Myllocerus subasciatus Guerin infesting brinjal (Solanum melongena L.) using Bacillus thuringiensis ssp. tenebrionsis. Acta Horticulturae, 503-508. https://doi.org/10.17660/ActaHortic.2004.638.64

Mosz, N. (2002). Walnut timeline. HIB/BEAD, 1-6.

Panzer, R., \& Schwartz, M.W. (1998). Effectiveness of a vegetation based approach to insect conservation. Conservation Biology, 12(3), 693-702. https://doi.org/10.1046/j.1523-1739.1998.97051.x

Perfecto, I., Vandermeer, J., Hanson, P., \& Carten, V. (1997). Arthopod biodiversity loss and the transformation of a tropical agroecosystem. Biodiversity and conservation, 6, 935-945. https://doi.org/10.1023/A:1018359429106

Perrins, C.M., Lebreton,J.D., \& Hirons, G.J.M. (1991). Bird population studies: Relevance to Conservation and Management. Oxford University Press, New York, USA: 7- 637.

Pinheiro, C.E.G., \& Ortiz, J.V.C. (1992). Communities of fruit feeding butterflies along a vegetation gradient in Central Brazil. Journal of Biogeography, $\quad 19, \quad 505-511$. https://doi.org/10.2307/2845769

Rajadurai, S., \& Thiagarajan, V. (2003). Mulberry sap sucking pests. Indian Silk, 8, 5-8.
Reddy, G.K.V., \& Moos, M.M. (2015). Insecta diversity, species richness and evenness of "The walking mango tree". Species, 15(48), 19-23.

Routledge, R.D. (1980). Bias in estimating the diversity of large, uncensused communities. Ecology, 61, 276-281. https://doi.org/10.2307/1935186

Stirling, G., \& Wilsey, B. (2001). Emperical Relationship between species richness, evenness and proportional diversity. The American naturalist, $\quad$ 158(3), 286-299. https://doi.org/10.1086/321317

Thomazini, M.J., \& Thomazini, A.P.B.W. (2002). Diversidade de abelhas (Hymenoptera: Apoidea) em inflorescencia de Piper hispidinervum (CDC). Neotropical Entomology, 31(1), 27-34. https://doi.org/10.1590/S1519566X2002000100004

Tomanović, Z., Brajković, M., Krunić, M., \& Stanisavljević, L.J. (1996). Seasonal dynamics parasitization and colour polymorphism of the pea aphids, Acyrthosiphon pisum (Harris) (Aphididae: Homoptera) on alfalfa in the south part of the Pannonian area. Tisua, 30, 45-48.

Tramer, E. J. (1969). Bird Species diversity: Components of Shannon's formula. Ecology, 50, 927-929. https://doi.org/10.2307/1933715

UCIPM. (2011). Pest Management Guidelines: Walnut. University of California. Agriculture and Natural Resources, 3471, 5-41. Available from http://ipm.ucanr.edu/PMG/selectnewpest.walnuts.ht $\mathrm{ml}$ (accessed on 1 October 2017).

Udikeri, S., Kranthi, S., Kranthi, K. R., Vandal, N., Hallad, Patil, S. B., \& Khadi, B. M. (2014). Species diversity, pestiferous nature, bionomics and management of mirid bugs and flower bud maggots: the new key pests of Bt cottons, World Cotton Research Conferences-5, Mumbai: 203-209. 